\title{
THE FREE TRADE AGREEMENT BETWEEN THE EUROPEAN UNION AND MEXICO - IMPACT ON TRADE AND FOREIGN DIRECT INVESTMENT
}

\author{
EL TRATADO DE LIBRE COMERCIO ENTRE LA UNIÓN EUROPEA \\ Y MÉXICO. EL IMPACTO SOBRE EL COMERCIO Y LA INVERSIÓN \\ EXTRANJERA DIRECTA
}

\author{
Antonio Manrique de Luna Barrios*
}

\begin{abstract}
The Free Trade Agreement between the European Union and Mexico (FTA EU-MX) has contributed to reactivate the economic relations between them since they have implemented the global agreement that came into effect in the year 2000 and that has permitted that the economic and trade relations between both parties have strengthened. However, it will be shown that there does exist the need to adapt the FTA EU-MX to the actual national, regional and international circumstances and to promote changes in order to gain more benefits for Mexico and its population.
\end{abstract}

Key words: Free Trade Agreement, Mexico, European Union, investments, trade.

RESUMEN: El Tratado de Libre Comercio entre la Unión Europea y México (TLCUEM) ha contribuido a reactivar las relaciones económicas entre ellos, ya que ha permitido, por un lado, implementar el Acuerdo Global que entró en vigor en el año 2000, y por otro, fortalecer las relaciones económicas y comerciales entre ambas partes. Sin embargo, se ha demostrado que existe la necesidad de adaptar el Acuerdo de Libre Comercio entre la Unión Europea y México a las circunstancias nacionales, regionales e internacionales actuales y para promover ciertos cambios con la finalidad de generar mayores beneficios para México y su población.

Palabras clave: Tratado de Libre Comercio, México, Unión Europea, inversiones, comercio.

\section{INTRODUCTION}

In the international setting a number of changes have taken place because of the globalization and the liberalization of global trade and a number of expectations have been created with respect to the benefits of the free trade agreements that have been signed by nations. However the process of commercial opening has not always resulted in fast and direct benefits especially in regard to the poorest parts of the population of the states.

Exactly these expectative of economic growth thanks to a free and healthy interchange of goods and services and the possibility to create new poles of development con-

\footnotetext{
* Doctor in Law, Master in International Studies, Master in International Trade, Lawyer. Professor of International Law and International Organizations at the University of Deusto. Avenida de las Universidades 24, 48007, Bilbao (Spain). Email: a.mdel@deusto.es
} 
vinced Mexico to sign a free trade agreement with the European Union within the context of a global agreement that touches politics, economics, social aspects and cooperation.

The process of a commercial opening of Mexico is a topic of great actual relevance that arouses and continues arousing a great interest of the European Union (EU) and has become a powerful instrument that contributes to the development of the Mexican people as far as it is implemented according with the interests of the population in general.

The context in which this free trade agreement was signed shows the wish of Mexico to increase its commercial relations with other international actors and which allows it to gradually abandon the commercial dependence that it had with the United States of North America. This way with the signing of the Free Trade Agreement with the European Union it was tried to increase the trade with this region and to incentivize the European investments in Mexico.

The hypothesis that we are following with this work considers that the commercial and economic relations between Mexico and the European Union have not produced the desired effects since Mexico has been used as a bridge to the United States of North Ameri$\mathrm{ca}$ and since it has not been regarded as essential and strategic for the trade of the European Union. Also an excellent opportunity was missed to consolidate it as an important link between the European Union and Latin America.

In that sense it is the objective of this investigation to realize an analysis and a presentation from the point of view of international trade and the rights of international business, the problems related to the interchange in trade between Mexico and the European Union, but without forgetting those aspects that should be improved so that Mexico could benefit from the free trade with the European Union and its investments in Mexican territory. On the other hand the European would have a strategic business partner with Mexico that would permit them to consolidate their position in the international setting.

Finally this investigation wants to: 1) Contribute to the establishing of a process of revision of the free trade agreement that Mexico and the European Union have signed. 2) Promote the use of free trade agreements as a mean that allows the population to reach a better level of economic well-being. 3) Contribute to society in general and rising consciousness about the importance of a smooth and free commercial interchange between states but with respect and healthy and free competence.

This present investigation uses different bibliographical sources. Also reports and documents of different Mexican and European institutions have been used, etc.

In regard to the structure of the present investigation, it is divided into several parts. In the first part the antecedents of the FTA EU-MX are analysed. In the second part the role of Mexico in the new trade strategy of the European Union towards Latin America will be studied. In the third part an analysis of the commercial interchange between the European Union and Mexico is realized. In the fourth part the - foreign direct investment of the European Union in Mexico is observed and in the fifth part the hypothesis planted will be discussed. In the sixth part the need to renegotiate the Free Trade Agreement between the European Union and Mexico will be studied and finally conclusions are presented and the bibliography that was used. 
Now we are going to analyse the first part of the present investigation with the objective to contextualize the FTA EU-MX.

\section{ANTECEDENTS OF THE FREE TRADE AGREEMENT BETWEEN THE EUROPEAN UNION AND MEXICO}

The antecedents of the Free Trade Agreement between the European Union and Mexico can be found in the first Frame Agreement, with economic and trade character that was signed by this country with the European Economic Community (now EU) in 1975. With this agreement, the in -those- days called European Economic Community, granted to Mexico which at that time was not a member of GATT, the treatment of a most favoured nation and this way contributed to the fact that Mexican exports towards Europe were stimulated and created a more favourable environment for the bilateral economic relations. We also have to say that another factor that contributed to the consolidation of this commercial relationship was the second Framework of Agreement of Cooperation which was signed on the $26^{\text {th }}$ of April 1991 and the Joint Solemn Declaration of the $10^{\text {th }}$ of April of 1995 that proposed to widen the relations between both parts with a vision of long-term time limit and that was aiming at reactivating the economic and trade relations that had been affected in the Eighties ${ }^{1}$. However, the preliminary negotiations had to overcome a number of inconveniences that came up from the Mexican authorities since the European institutions planted the need to incorporate a "democratic clause" in the new commercial agreement. The incorporation of this disposition generated a strong initial rejection since it was considered an intervention into internal Mexican affairs and this impasse could only be solved thanks to making the above mentioned clause more flexible and by changing it by eliminating every reference to the expression "internal politics" 2

Once these impasses were overcome a number of negotiations took place and two agreements were signed that had a great impact on the relations between the European Union and Mexico. These agreements are the following: The Agreement of the Economic Association, Politic Consultation and Cooperation ${ }^{3}$ and the Internal Agreement about Trade and questions related with trade between the Mexico on one side and the European Community and its state members on the other side ${ }^{4}$. The agreements referred to were

\footnotetext{
${ }^{1}$ GonZÁLEZ (2003) pp. 139-178. The diplomatic relations between Mexico and the European Union were established in 1960. However, it was in 1975 when the first Frame Agreement with economic and commercial character was signed between them.

2 The incorporation of the democratic clause in the commercial agreements that are underwritten between the European Union and third countries. The text that almost hindered the commercial negotiations originally was as follows: "The respect for the democratic principles and the fundamental rights, as declared in the Universal Declaration of the Human Rights, inspires the internal and international politics of the parties and constitutes an essential element of the present agreement".

3 The Agreement of Economic, Political Consultation and Cooperation Association was approved by the Council of Ministers of the European Union on the $14^{\text {th }}$ of February 2000 and by the European Parliament on the $16^{\text {th }}$ of March 2000.

${ }^{4}$ The interim agreement about trade and questions related to trade between the European Union and the United States of Mexico was approved by the Senate of Mexico on the $23^{\text {rd }}$ of April 1998 and by the European
} 
aimed at being part of an agreement with integral association that would be developed in three areas: the promotion of a continuing political dialogue between Mexico and the European Union, the creation of a free trade zone between both parties where investments were promoted, among other aspects and the establishing of an intense cooperation between the parties of the agreement.

It has to be mentioned that due to the complexity that implied carrying out the negotiations for establishing a free trade zone between both parties, it was decided to implement an "Interim Agreement" that previously allowed to establish certain customs duty liberties before the global agreement above mentioned finally was reached. Later when the establishment of a global agreement was reached on the 1 st of July $2000^{5}$, the interim agreement was not applicable any more since the Article 16 of the above mentioned international treaty had been established ${ }^{6}$.

From this perspective it can be said that this agreement represented an important possibility for Mexico given the advantages that it implied being associated with the European Union from a commercial point of view since they had come along since a long time ago from the political point of view and from cooperation in terms of relations between both zones ${ }^{7}$. On the other side, the European Union that has been working on establishing itself as an important actor in the international society saw a great challenge and a great opportunity in this process since it considered Mexico a valid interlocutor in the Latin American region which would allow the European Union to enter into this region just as it is happening at the moment. However, the special situation of Mexico has to be considered, because since the beginning of the North American Free Trade Agreement in 1994, Mexico has without any doubt become more closely connected with the United States of North America.

In this context it has to be indicated that the European Union tried with the Free Trade Agreement that it signed with Mexico to enter into the Mexican market with a similar tariff reduction as foreseen in the North American Free Trade Agreement, that means it wanted to count on a "parity with the North American Free Trade Agreement" and it also wanted to protect its investments. The trade agreement with the European Union represented for Mexico the possibility and the opportunity to diversify its commercial relations with other international actors and to change a situation that reflected a high concentra-

Parliament on the $13^{\text {th }}$ of May 1998. The interim agreement referred to entered into effect on the 1 st of September 1998.

${ }^{5}$ Due to its nature the global agreement required the approbation of the European Parliament and the national parliaments of the state members of the European Union at this moment (15 states).

${ }^{6}$ In the article 16 of the interim agreement about trade and questions related to trade between the United States of Mexico on one side and the European Community and its member states on the other side established in regard to its duration the following: "The present agreement will be applicable till the signed global agreement will come into effect on the $8^{\text {th }}$ of December 1997. Each one of the parties can denounce the agreement after advising the other party. The present agreement will not be applicable any more six months after the date of such a notification".

7 Gómez (2005) pp. 67-75. 
tion of its commercial relations on the United States of North America. It also meant the increase of room for manoeuvre and influence of Mexico in the world ${ }^{8}$.

It can be seen that starting form this actions Mexico began to leave the commercial bilateralism in which it had developed its activities before and started to enter into a multilateral practise that allowed it to act in a global environment and to find new partners that would back up its active participation in the international society ${ }^{9}$. However, there was a certain fear that Mexico would only be used as a platform for the EU to enter into the market of NAFTA, but the strict norms of this treaty put on the brakes in certain ways to these fears since the products needed a great number of primary resources originally coming from North America to really benefit from the advantages of the NAFTA agreement. And regarding this situation, Europe had to rethink its objectives and understand that in order to enter into the U.S. market it would have to invest and establish industries in Mexico that would use the input from the region of North America and Mexico could not only be used as a mere platform ${ }^{10}$. It was also thought that the presence of the European Union would provoke a greater commercial independence between Mexico and the United States of North America, which was the commercial objective of the EU. However, we cannot negate that the commercial interchange between Mexico and the United States is and will continue to be the most important one for Mexico.

One of the main critiques that have been made during the process of negotiations from the Mexican side is based on the fact that the Mexican negotiators were concentrated excessively in the subject of tariff barriers and that they left aside the topic of non-tariff barriers. According to the opinion of Rodolfo Cruz Miramontes this was a mistake because "the maturity of the European governments leads them to accept and to carry out a game within the framework and the spirit of the free trade, but providing help and protection to its producers and consumers, in a way that it is always good for them"11. But it has to be reiterated that it was difficult for Mexico to change the relationship of dependence of the United States of North America which commercial politics is based on the NAFTA.

Once that we have presented the negotiations and the signing of the FTA EU-MX it is suitable to see how this trade agreement can contribute to the consolidation of Mexico as an important interlocutor in the relations between the European Union and Latin America.

\section{THE ROLE OF MEXICO IN THE NEW COMMERCIAL STRATEGY OF THE EUROPEAN UNION TOWARDS LATIN AMERICA}

In the international scenario of the moment the interests of the European Union in Latin America have increased and, especially the relations with Mexico have won considerably in importance since Mexico is considered a priority partner by the $\mathrm{EU}^{12}$. We have to

\footnotetext{
8 GREen - (2000) pp. 4-5.

9 Thorpe (2003) pp. 89-94.

10 World Trade Organization (2013) pp. 38-52.

11 CRUz (2003) p. 153.

12 PIÑon (2005) p. 17. During the Eighties the European Union did not give a lot of importance to Latin America because its main focus was centered on the disintegration of the Socialist block and its policy of neighborhood.
} 
indicate that this change in the European trade policy did not happen because of Mexico, but because the European Union was obliged for other reasons, among which we have to mention the eventual subscription of the Free Trade Area of the Americas (FTAA), which could have affected its position in this region. Some authors have started to indicate that the European Union tends to give each time more privileges to individual countries and consider this even more than its links with a whole region ${ }^{13}$. However, we do not share this vision since the European Union did not reach a block to block agreement with the Andean Community of Nations, but it should be remembered that this block to block agreement ${ }^{14}$ was not concretized because Bolivia and Ecuador decided not to participate regardless of the European efforts to maintain a block negotiation ${ }^{15}$. Another example of the will of the European Union to carry out negotiations from block to block is the Association Agreement that it signed with the Central American Common Market. Taking into account these specific cases we cannot generally say that the European Union does not want to realize wider negotiations with Latin America and that it rushes into specific agreements with particular countries.

Among the principle reasons for negotiating with Latin America we can find: the economic growth of this region, the commercial policy of opening, the claim for entering and getting installed in the international scenario, etc. ${ }^{16}$. In terms of the reasons for the European Union to try to primarily establish economic and commercial relations with Mexico we should mention: the recognition of the regional leadership position that Mexico has taken over for a long time in this region, the possibility for its investors to benefit from the preferential access to the market of the United States of North America thanks to the dispositions established in the North American Free Trade Agreement (NAFTA). With the objective to intensify the commercial relations with Mexico, the coming into effect of the NAFTA on the $1^{\text {st }}$ of January 1994, the European Union was trying to sign a global agreement with Mexico that would touch topics such as trade, politics and cooperation, but the opposition of France (main beneficiary of agricultural subsidies) slowed down the possibility to enter into negotiations about this specific subject. The European Union signed within the frame of its

\footnotetext{
13 Ruano (2013) pp. 619-644.

${ }_{14}$ The negotiations between the Andean Community of Nations and the European Union were established with the Decision 598 of the Andean Council of Foreign Ministers in an open meeting with the Commission of the Andean Community, that established that the Country Members could negotiate commercial agreements with third countries in a joint way or in block and exceptionally in an individual way. This way it was tried to obtain a major capacity to negotiate in regard to third countries or blocks of countries and to use these agreements as instruments to continue deepening the integration and the levels of economic development between the members of the Andean Community of Nations. Also we must indicate that these negotiations between blocks were affected by the participation of Ecuador and Bolivia in the ALBA-TPC given the fact that this negotiation did not want to develop the cooperation and the political dialogue and that even more it wanted to give more importance to the commercial side and was an excuse to promote a simple free trade agreement. Later, within the framework of the European Union it was established the possibility to establish negotiations only with Peru and Colombia given the fact that within the framework of the Andean Community of Nations no consensus had been reached in topics such as trade, sustainable development and intellectual property. Manrique de Luna (2015) pp. 817-827.

15 Now, Ecuador has concluded negotiations with the EU with regard to the signing of a FTA and soon a FTA will be signed.

16 Sanahua (2013) pp. 1-32.
} 
relations with Mexico finally the EU-Mexico Economic Partnership, Political Coordination and Cooperation Agreement (Global Agreement) which is in force since the year 2000 and where a Free Trade Agreement between the European Union and Mexico is included (FTA EU-MX $)^{17}$. This was the first free trade agreement between America and Europe.

With respect to the FTA EU-MX we have to say that it was surrounded by a state of optimism which tried to show evidence at every moment of the benefits that could be generated since its signing. So the delegation of the European Union in Mexico indicated that the agreement opened a great opportunity to expand and to increase participation in the reciprocal markets and that access to input, machines and technology could be obtained $(\ldots)^{\prime 18}$. Also, they pointed out that the experience in former free trade agreements and the economic theory generally indicated a positive effect of liberation in the area of creation of trade and employment: but the magnitude and the characteristics of such an impact depended on different factors and circumstances.

The strategy of the European Union to try to stimulate its relations with Latin America (especially with Mexico, Chile, Peru and Columbia) was oriented at establishing itself as an important actor in the International Society ${ }^{19}$. However, the economic crisis that affects the EU at the moment and the problems that the Eurozone present have prevented it from carrying out its capacities in the international scenario ${ }^{20}$. But the FTA EU-MX was harshly criticised since it came into effect because neither the different product chains have been considered nor the small and medium-sized companies (SMEs). To demonstrate the above mentioned, we can indicate that the international trade of the SMEs does not result in a better distribution of economic income in the production or distribution chains of the Mexican economy because the exports do not generate jobs or significant real wages in the SMEs. About this topic Sánchez Barajas tells us "that it is true that in some years the exports have represented more than $30 \%$ of the GDP, and also that there were some companies that realized $93.0 \%$ of the total export (...) in that way that $7.0 \%$ of the remaining Mexican sales abroad come mainly from medium sized companies and to little extend, from the SMEs" 21 .

We also have to indicate that the economy of scale is an aspect that can hardly be found in the SMEs and this has the effect that they lose competitiveness in comparison with the great companies. We consider that it is fundamental that the SMEs can benefit from the advantages that the FTA EU-MX present and that they can get together and can compete in a collective way directly or indirectly providing input for the great exporters. However, we believe that the participation of the state is essential so that the producers of

\footnotetext{
17 The Global Agreement between Mexico and the European Union has come into effect since the 1st of October of 2000 and the Free Trade Agreement that both parts have signed since the 1st of July 2000. The Free Trade Agreement between the European Union and Mexico (FTA EU-MX) is known as well as the interim agreement about trade and questions related with trade.

18 https://ec.europa.eu/europeaid/sites/devco/files/csp-mexico-2007-2013_en.pdf.

19 https://ec.europa.eu/europeaid/sites/devco/files/csp-mexico-2007-2013_en.pdf.

20 Guillén (2013) pp. 23-41.

${ }^{21}$ herzog.economia.unam.mx/profesor/barajas/perspec.pdf.
} 
the SMEs can be oriented, organized and motivated so that major advantages can be generated in a coordinated way against comparative ones ${ }^{22}$.

It has also been indicated that there does exist a trade deficit that affects Mexico and that it will be difficult to get liberated from it. Meanwhile, within the European Union, it is insisted on the fact that the NAFTA goes much further beyond and that it is not limited to mere commercial aspects.

We consider that the European Union should take the opportunity that offers the global agreement with Mexico from a commercial point of view, but that it should not forget its values that should always inspire its actions. It should also remember that with Mexico it can find an access to the markets of Latin America.

Above we are going to analyse the interchange that was conducted between the parts that signed the FTA EU-MX.

\section{THE IMPACT OF THE FTA EU-MX ON THE COMMERCIAL INTERCHANGE BETWEEN THE EUROPEAN UNION AND MEXICO}

With the signing of the FTA EU-MX it was aimed at increasing the Mexican exports to one of the most important markets of the world as it is the EU (the main clients of Mexico within the European Union are: Germany, Spain, United Kingdom, France and Holland). At the moment the market of the EU is integrated by 28 countries and opens access to a number of 508 million of potential consumers.

It was also tried to reach that the European investments would position in Mexico and that they would contribute to the economic growth of the country. The FTA EU-MX should be considered as an instrument that permits Mexico to diversify its markets and to reduce the commercial dependence of the United States of North America that has been enhanced with the NAFTA. We should remember that the NAFTA is the most important commercial agreement that Mexico has signed. In addition it is aimed at maximising the strategic alliances between the Mexican companies and the European ones. Meanwhile the European Union is trying to synchronize the entering into the Mexican market with the open access that offers this country to the United States of North America and Canada.

In applying the dispositions of the FTA EU-MX, it was established that Mexico should enjoy a one hundred per cent tax relief on its industrial products when they entered into the market of the European Union and as the final date was put 2003. Meanwhile, starting from 2007, the industrial products that come from the European Union and enter into Mexico do the same. However, many of these products come from Mexican branches of European companies. So for example, the exports of Mexican automotive products (that represent more than $17 \%$ of the exports) have assumed an important role within the Mexican exports to market of the European Union. This makes us think that the Mexican industrial exports strengthen the European industry that can see itself being repowered with the industrial products that enter from its Mexican branches into the market of the EU.

22 Krugman \& Obstfeld (2001) pp. 315-320. 
We have to indicate that the FTA EU-MX addresses in eleven chapters the following topics: market access ${ }^{23}$, rules of origin ${ }^{24}$, technical norms, sanitary and phytosanitary - measures (SPS - measures) ${ }^{25}$, safeguards ${ }^{26}$, investments and related payments, trade in services, sales in the public sector ${ }^{27}$, competences, intellectual property, solving of controversies.

It should be mentioned that with the FTA EU-MX certain advantages were granted to the European Union that had not been granted to any other partner with a free trade agreement signed by Mexico at the moment. So, for example it was established that within 10 years starting from the point when the FTA comes into effect a total liberalization of the trade in services would take place. But we have to remember that certain restricted areas exist in Mexico in regard to - foreign direct investments, but the reforms that have been carried out by the Political Constitution of Mexico (Article 25, 27 and 28) and other specific laws have almost eliminated these restrictions to the foreign investments in the energetic sector.

Now we will analyse the evolution of the trade balance between Mexico and the European Union starting from 1999 till 2013 with the objective to determine certain aspects related to the trade deficit that affects Mexico.

\section{GRAPHIC 1}

Commercial balance between Mexico and the EU between 1999 and 2013 (Millions of euros)

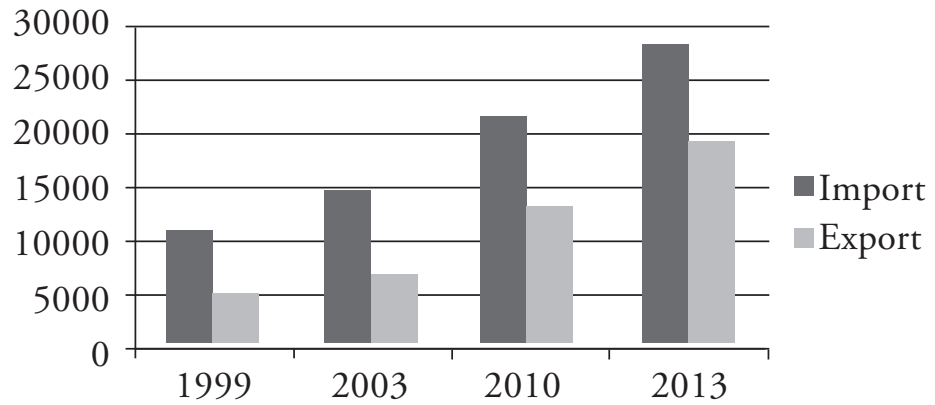

Source: Delegation of the European Union in Mexico \& Eurostat.

23 In this area aspects were incorporated that were linked with the national treatment and the non-discrimination. In the FTA EU-MX the asymmetries between both parts were recognized and different deadlines for the tax relief were established. So the European taxes reduction ended in 2003 and the Mexican one in 2007.

24 The goods that contain input that has not come from any of the 28 countries of the EU or Mexico should be transformed in any state which is part of the FTA EU-MX and the transformation should be that way that its tariff classification is changed. So, for example the rules of origin that were established in the automobile sector benefited Mexico in the way that it allowed the state members of the EU to export vehicles and its parts.

25 The FTA EU-MX has established a special subcommittee that comes together every year with the objective to interchange information, offer solutions to problems that occur in relationship with access to products and to accept certain areas free of diseases and to offer an adequate animal and plant protection to the consumers from Mexico and the EU.

26 In the Free Trade Agreement between Mexico and the EU a bilateral safeguard has been recognized (that applies to the imports that derive from the application of this agreement) and the global safeguard (that applies to the imports coming from the rest of the world).

27 In the area of the sales in the public sector a gradual opening has been established that includes the buying of the companies of the federal government. 
As we can see in graphic 1, in the year 1999 (before the FTA EU-MX came into effect), the exports from Mexico to the European Union had an amount of 4.949 million of euros, while the imports of Mexico from the European Union ascended to an amount of 10.585 . On the other hand, in the year 2013, the Mexican imports from the communitarian market summed up to an amount of 28.000 million of euros and the exports to the market of the European Union came up to an amount of 19.000 million of euros.

From the graphic we can infer that the trade balance between Mexico and the European Union continues to generate an important deficit for Mexico regardless of the fact that the Mexican exports have risen in a considerable way. So for example, between 1999 and 2010, the exports from Mexico to the European Union grew by $165 \%$, that means, on a more sustainable pace than its imports that only increased by $102 \%$.

It also has to be indicated that in relative terms the amount of exports has covered a major percentage of the imports, but still it tends to maintain its absolute value. A quick look on the indicators could lead us to the assumption that the trade balance continues to be disadvantageous for Mexico and that the effects of the FTA-MX-EU have not brought the wished and expected effects. However, we should not forget that the trade deficit for Mexico already existed before the signing of the FTA EU-MX ${ }^{28}$.

During the year 2013, as it can be seen in the graphic 1, the imports from the European Union to Mexico ascended 28.000 million of euros, while the Mexican exports to the European Union were 19.000 million of euros. However, we should show that the exports from Mexico to the European Union have risen by 204\% in relationship to 1999.

As reasons for this have to be mentioned the good performance of the European economy for many years (before the crisis), the stability of Germany (as a motor of the European economy) and the incorporation of the new state members of the European Union. All these factors could have influenced this increase. Finally, the increase of the commercial activity does not necessary mean that the Mexican companies have improved their competitiveness or that the Mexican companies have grown a $\operatorname{lot}^{29}$.

With respect to the structure of the imports from the European Union we can indicate that in 2013 they represented a rise of $14.2 \%$ in comparison with the level in 2013 and $301 \%$ in comparison with the level in 1999. However, the fact that many Mexican imports are semi-elaborated makes us think that Mexico continues to be used as a fabric of transformation that uses these products to later export them again.

The members of the European Union that have been the main receptors of the Mexican exports are: Germany, Spain, United Kingdom and France. In regard to the products that have been imported, we must indicate that no transformation has taken place and that they continue to be machines and material of transport, chemical products and basic manufactured goods.

\footnotetext{
28 The deficit of the trade balance between Mexico and the European Union existed before the signing of the FTA-EU-MX, and after its signing, continued increasing in disadvantage of the Latin American country. So, for example, the deficit referred to were 5.636 million of euros in 1999, of 7.843 million of euros in 2003, 8.277 million of euros in 2010 and 9.000 million of euros in 2013.

29 https://ec.europa.eu/europeaid/sites/devco/files/csp-mexico-2007-2013_en.pdf (accessed February 17 ${ }^{\text {th }}$, 2015).
} 
Now we are going to approach the form in which the European investments are carried out in Mexico with the objective to show its contribution to the Mexican development and the aspects that can be improved in a future renegotiation of the FTA EU-MX.

\section{THE FOREIGN DIRECT INVESTMENT OF THE EUROPEAN UNION IN MEXICO}

With the legal reforms that Mexico has carried out in the area of foreign direct investment and the entering into the FTA EU-MX, other industrialized countries wanted to establish themselves in Mexico. Also with the FTA EU-MX a number of conditions were created that were trying to promote the foreign direct investment of companies and investors of the EU and Mexico in a way that there were not demanded any special requirements for performance as a condition to approve the investment or to grant an incentive for the investment. Also the possibility of the state to intervene into the economy was limited, the liberty of circulation of capital was established (free currency convertibility and the transfer abroad) and it was permitted to claim the state in case of indirect expropriations.

It was the idea to attract capital, technology and to give major export capacity to the Mexican industrial sector either with direct investments or with the establishing of strategic alliances between Mexican companies and the European Union. However, with the FTAEU-MX the possibility was established to take means that prevent the flow of capital when there was exchange, monetary or balance of payments risks. The need was established to inform the partner of the Agreement without any delay and to submit a plan for elimination. In general we have to indicate that these dispositions are common in all Free Trade Agreements and that in the case of the FTA EU-MX the approach was used as in NAFTA.

In actual terms we have to indicate that the FDI of the European Union has grown in Mexico. In 2013 the European Union has been the second source of FDI in Mexico (bringing in 38\% of the FDI in Mexico since 2000).

GRAPHIC 2

Change ef the FDI of the Europe Union in México (Millions of U.S. dollars)

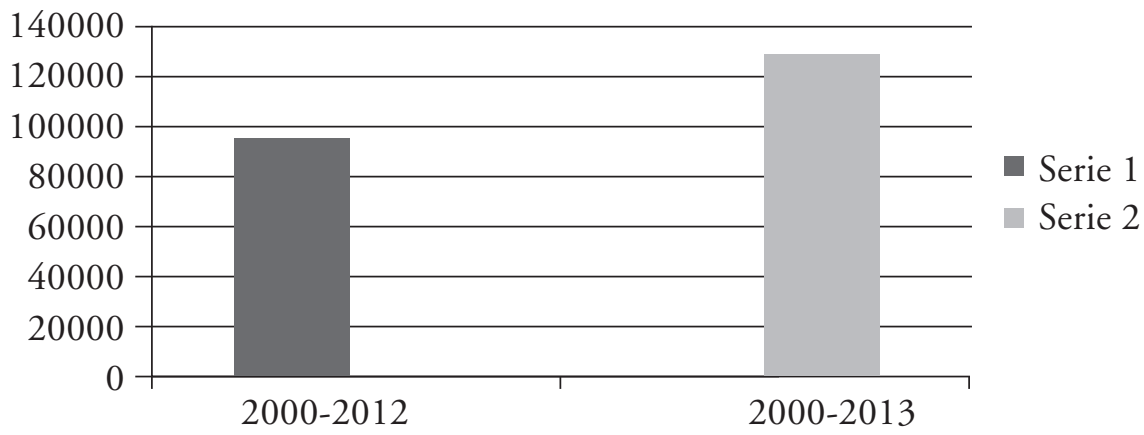

Source: Delegation of the European Union in Mexico. 
As we can observe in the graphic 2, in the time frame from 2000-2012, the FDI of the European Union in Mexico had an amount of 95,175 million of U.S. dollars ${ }^{30}$. During 2000-2013 the FDI of the EU in Mexico was 128,800 million of U.S. dollars ${ }^{31}$. This way it keeps demonstrated that the confidence of the European business sector in Mexico remains and that there is a tendency to increase as soon as the effects of the expected reform in the energetic sector take place. However, the European companies that have established their production in Mexico have increased their capacity to compete internationally and to reduce the cost of production and they can take advantage of the net of FTA that gives Mexico access to several markets ${ }^{32}$.

The main countries that have invested in Mexico and that are part of the European Union are the following: Spain, Belgium, Holland, Germany and U.K. And the main sectors that the European investments go to in general are: services (professional, real estate, banking, tourism, hotels, etc.), - trade, construction, transport and communications, agriculture, mining, etc.

The foreign direct investment that entered into Mexico in 2013 came from the following countries Belgium (37.7\%), United States of North America (32.0\%), Holland (7.6\%), Japan (4.4\%), Germany (3.6\%), United Kingdom (3.3\%) and the rest $(11.4 \%)$. According to the Secretary of Economy of Mexico, there are 1253 societies with German participation in Mexico that generate about one hundred twenty thousands of jobs ${ }^{33}$.

In the area of services we can indicate that in the financial sector the Mexican banks were bought by European capital. So for example the Spanish capital has bought Bancomer (which was bought by Banco Bilbao Vizcaya Argentaria Group), Serfin (which was bought by the Santander Group) and the English capital which bought HSBC. At the moment these banks control more than $50 \%$ of the commercial bank of the country.

With the structural reforms that have taken place in the sector of energy it can be expected that the European FDI will increase in Mexico and the European entrepreneurs can carry out their investments after having waited for quite some time for this structural reform. However, this new opportunity shall generate direct benefits for the Mexican people who should be the ones to benefit the most from the exploitation of their natural resources and it corresponds to the respective authorities to guarantee that their citizens can leave extreme poverty and that they finally feel included socially.

\footnotetext{
30 Gutiérrez - Haces (2014) pp. 25-52.

31 Between 1994-2010 have entered 108,000 million of US dollars have entered to Mexico as foreign direct investment. The entering of 93.800 million of US dollars happened between 2000 and 2010 .

32 The main FTAs that Mexico has signed are: North American Free Trade Agreement; FTA with Colombia; Free Trade Agreement with Bolivia; Single Free Trade Agreement with Central America; FTA with Chile; FTA with Peru; Framework Agreement and Additional Protocol to the Framework Agreement of the Pacific Alliance; Free Trade Agreement with the European Union (FTA); Free Trade Agreement with Israel; FTA with the European Free Trade Association; FTA with Uruguay; Agreement for the Strengthening of the Economic Partnership Agreement between Mexico and Japan; etc.
}

33 Alcántara (2013) pp. 33-59. 
In the following part of the investigation we will talk about the need to actualize the FTA MX-EU and to give it an approach that will generate better benefits for Mexico and its population.

\section{PROVING THE HYPOTHESIS BY CONSIDERING THE MEXICAN AUTOMOBILE SECTOR}

With the objective to accredit the planted hypothesis we are going to plant and to answer the following questions: Which was the sectorial destination of the investment of the European Union in Mexico? Which was the grade of integration of the European investment with the national production? What size did the commercial flow to the United States have? Now we are going to evaluate these aspects.

\subsection{WHICH WAS THE SECTORIAL DESTINATION OF THE INVESTMENT OF THE EUROPEAN UNION IN MEXICO? \\ Regarding the sectors of the Mexican economy in which the European Union has} carried out its investment we have to indicate that between 2000 and 2012 the flow of investments of the European Union in Mexico was aimed towards the sector of the manufacturing industry with the objective to gain benefits from the advantages that this sector offers for the European companies. To show the levels of investment of the EU in the different sectors of the Mexican economy we will see the following graphic.

GRAPHIC 3

Flow of investment of the EU in Mexico by sector (2000-2012)

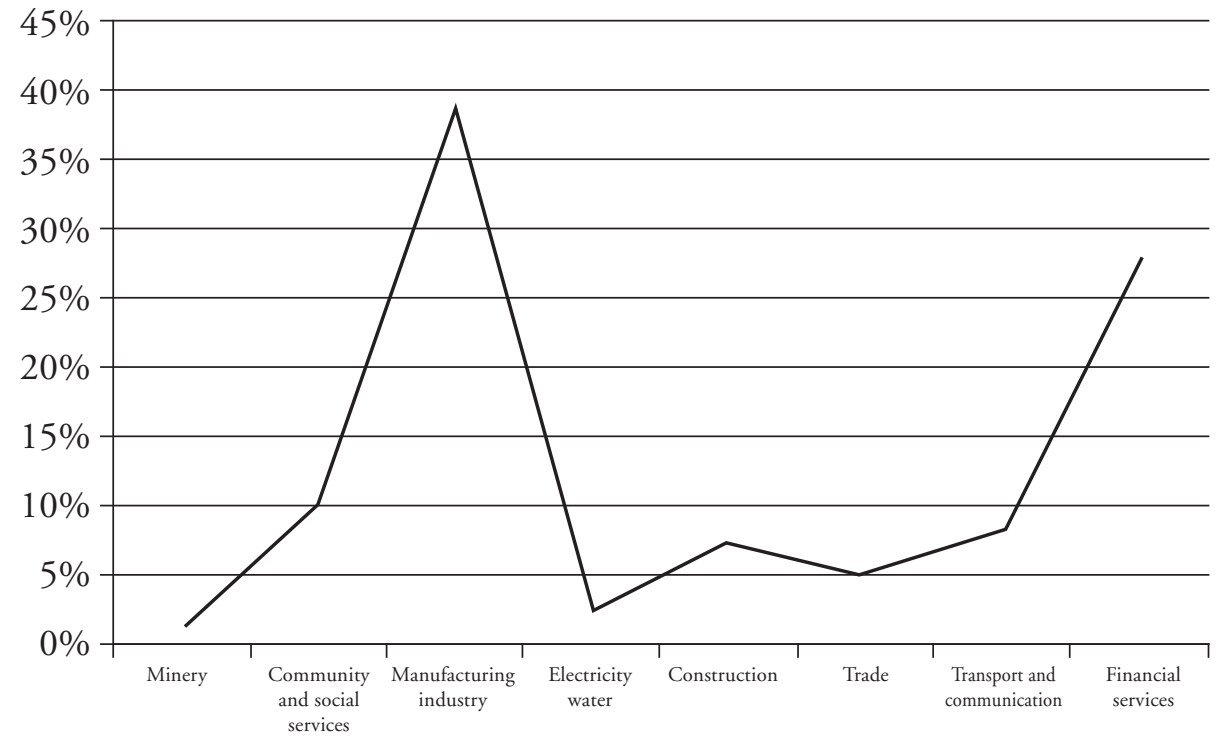

Source: Secretary of Economy of Mexico. 
As we can observe in the graphic 3, in the period from 2000-2012, the manufacturing sector is the main receptor of - foreign direct investment of the EU in Mexico with an amount of 41,545 million of U.S. dollars, which represents 39\% of the total amount invested by the European Union ${ }^{34}$. Also the financial, transport and communication sector have benefited from these investments. To outline the hypothesis of this article however we will only concentrate on the manufacturing industry and in a special way the subsector "automobile" with the objective to show how the European Union has acted in Mexico and how it has carried out its investments in this subsector. This way we have to indicate that the -foreign direct investments between 1999 and 2014 (third trimester) that the European Union has carried out in the automotive sector have been important, constant and were represented by Germany with an FDI of 3,628 million of U.S. dollars (10\% of the FDI in this subsector) and by the Netherlands with a FDI of 2,261 million of U.S. dollars (6.2\% of the FDI in this subsector). However, it can be considered that they try to get established in Mexico with the objective to export their products to the market of the United States of North America instead of considering Mexico as an essential and strategic destination for their economic activities.

In order to proof our hypothesis we will continue to regard the fact if Mexico is a place from where it can be exported easily towards the United States of North America and for this reason we will evaluate the level of integration of the investment coming from the EU into the Mexican production.

\subsection{WHAT HAS BEEN THE LEVEL OF INTEGRATION OF THE EUROPEAN INVESTMENT WITH THE NATIONAL PRODUCTION?}

Continuing with studying the sector of the manufacturing industry and especially the automobile subsector we can indicate that the European investment has been integrated into the national production in the following way:

\section{GRAPHIC 4}

FDI in the automotive sector

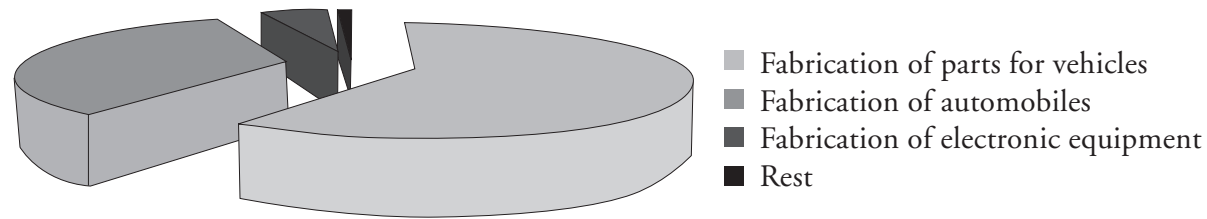

Source: Secretary of Economy.

With the graphic 4 it is shown how the FDI is integrated with the Mexican national production. This way we can indicate that $60 \%$ of the FDI in the automotive sector is destined to the fabrication of parts for automotive vehicles, $34 \%$ is destined to the fabrication

\footnotetext{
34 In 2014 the Secretary of Economy reported that the -foreign direct investment from the European Union in Mexico between 2000 and 2014 (January-September) had an amount of 141,951 million of US dollars; the FDI of the United States of North America summed up to 167,529 million of US dollars.
} 
of automobiles and lorries, $5 \%$ is for the fabrication of electronic equipment and its parts for the automobile vehicles and $1 \%$ is for other related activities.

Regarding to the companies that have carried out the production of the exported products we have to say that they have mainly been carried out by European transnationals installed in Mexico ${ }^{35}$.

According to Gutiérrez-Haces we consider that the European companies in general are not looking to invest in Mexico under the scheme of maquiladora but that they in fact subcontract the European SMEs established in Mexico to operate in tandem and to this way leave apart a considerable number of Mexican SMEs which has led to questioning efficiency of the Global Agreement for Mexico ${ }^{36}$.

The participation of Mexican micro, small and medium-sized companies (MSMEs) in the area of export has been reduced. However it - should be promoted because with this participation the benefits of the free trade agreement can reach several economic sectors of the society and at the same time it can socially include the different sectors of the population.

It is necessary that the MSME will be a mechanism that allows with success to stop the constant competence imposed by globalization and to reach this it is necessary that the Federal Government helps to promote this type of initiatives ${ }^{37}$. We should also indicate that at the beginning the European small and medium sized companies exported their products to Mexico, but that later when they were better consolidated they decided to install their production centres in this country ${ }^{38}$.

Summarizing this means that Mexico needs to improve its competitiveness and to innovate technology in order to avoid that it is used as a trampoline to supply European input, fabricate products in communitarian companies and to export them to the United States. It is necessary that they take advantage of the FTA EU-MX and that productive chains are created that help to grow new industrial sectors; the internal competitiveness has to be promoted so that the entrepreneurs have more chances; they have to be given the necessary support so that the companies can receive the financing required in order to explore new markets and to diversify their foreign trade, etc.

\subsection{What is THE SizE OF COMMERCial FLOW TOWARdS THE United STATES?}

The size of commercial flow will permit us to show if the commercial activity of Mexico has geographically diversified or if it continues to present an elevated concentration on the United States of North America.

35 CHACón (1996) pp. 159-193.

36 Gutiérrez - Haces (2014) pp. 25-52.

37 Conde (2004) pp. 78-103.

38 Taking these aspects in account, in October 2014, the Mexican Institute of Entrepreneurs (Inadem) signed together with the Sub-Secretary of Economy of Germany an agreement with the objective to provide formation to the executives of small and medium-sized Mexican companies. 
TABLE 1

Total exports from Mexico to the United States of America and the European Union

(1995-2013)

In millions of US\$

\begin{tabular}{|c|c|c|c|}
\hline & USA & EUROPEAN UNION & TOTAL \\
\hline 1995 & 66,273 & 3,371 & 79,541 \\
\hline 2000 & 147,399 & 5,742 & 166,120 \\
\hline 2005 & 183,562 & 9,141 & 214,232 \\
\hline 2010 & 238,684 & 14,430 & 298,473 \\
\hline 2013 & 299,439 & 19,704 & 380,025 \\
\hline
\end{tabular}

Source: Subsecretary of Foreign Trade, Secretary of Economy of Mexico.

Between 1995 and 2013 there has taken place an important change in regard to the amount exported to the European Union. This way the export to the European Union has increased from 3,371 million of US dollars to 19,704 million of US dollars in 2013.

But the exports from Mexico have not diversified geographically and present an elevated concentration - on the United States of North America. So for example, in 1995, the exports of Mexico to this country where around $83 \%$ of its total world-wide exports; the exports to the European Union have maintained constant around $4 \%$ of the total export by Mexico to the world. However, the amount of Mexican exports to the European Union has increased from 1995 to 2013 in 16,333 million of US dollars. This positive result has not been sufficiently successful so that the international economic relations of Mexico in the world are still limited by and depend on the politics and economic relations with the United States of North America.

With the objective to demonstrate the hypothesis of the work it is convenient to analyse the Mexican exports in the automobile sector because in this sectors many investments of the European Union have taken place. Till now the light vehicles that Mexico has sold abroad the majority has been sent to the United States of North America, representing $71.2 \%$ of all the exports.

We are going to present the following table with the objective to demonstrate that the companies of the European Union that have invested in Mexico, especially in the production of light vehicles, are mainly aiming to target their production to the United States of North America as their final destination 
TABLE 2

Destination of Mexican exports of light vehicles

In millions of US\$

\begin{tabular}{|c|c|r|r|r|r|}
\hline Ranking 2014 & Country & $\begin{array}{c}\text { Jan - Oct } \\
2013\end{array}$ & $\begin{array}{c}\text { Jan - Oct } \\
2014\end{array}$ & Participation & Porcentual Change \\
\hline 1 & USA & 1,371 & 1,574 & $71 \%$ & $14,8 \%$ \\
\hline 2 & Canada & 163 & 226 & $10 \%$ & $38,7 \%$ \\
\hline 3 & Brazil & 118 & 88 & $4 \%$ & $-25,7 \%$ \\
\hline 4 & Germany & 109 & 74 & $3 \%$ & $-31,8 \%$ \\
\hline
\end{tabular}

Source: Mexican Association of Automotive Industry (MAAI).

From the countries that provide light vehicles to the United States of North America, Mexico presents between January and October of 2014 a rate of growth of $14.8 \%$ in comparison to January-October 2013. We can observe that Canada was the country that presents a major change in terms of percentage, but United States continues to be the most important market for Mexican exports of light vehicles. This graphic show that the automobile industry (one of the most important ones in Mexico) has increased substantially its export capacity and this way the generation of devises for Mexico. So, for example during the period of January-August of 2014 the automobile balance was surplus with 31,795 million dollars, while the national trade balance was in deficit of $-2,352$ million of dollars.

Now we are going to realize an evaluation with respect to the imports that Mexico carries out from the United States of North America and from the European Union.

TABLE 3

Total imports of Mexico to the Unites States of America and the European Union (1995-2013)

In millions of US\$

\begin{tabular}{|c|c|c|c|}
\hline & USA & EUROPEAN UNION & TOTAL \\
\hline 1995 & 53,902 & 6,811 & 72,453 \\
\hline 2000 & 127,534 & 15,070 & 174,457 \\
\hline 2005 & 118,547 & 25,775 & 221,819 \\
\hline 2010 & 145,007 & 32,422 & 301,481 \\
\hline 2013 & 187,261 & 42,693 & 381,210 \\
\hline
\end{tabular}

Source: Subsecretary of External Trade, Secretary of Economy of Mexico.

As we can see from the graphic before the sales of the European Union to Mexico have risen since the FTA EU-MX came into vigor.

This way between the years 1995 and 2013 an important growth has taken place in the Mexican imports from the European Union. So, for example the numbers have gone up from 6,811 million US dollars to 42,693 million US dollars. However, the United States of North America continues to be the major provider of Mexico. 
We have to indicate that the sales of the European Union towards the Mexican market have risen since the FTA-EU-MX came into vigor; the results of the Agreement are notable by comparing the amounts indicated before and reflect a growth of $600 \%$ with respect to 1995 .

From the graphics presented we can conclude that the signing of the FTA EU-MX has not served in a way that Mexico can diversify geographically its exports; on the contrary, since the coming into vigor of the Agreement an increase of the products originally coming from the European Union into the Mexican market can be seen. The participation that the European Union has within the total Mexican sales represented $11 \%$ in 2013, a fact that would suggests that the FTA-EU-MX has permitted to diversify the Mexican imports, -but not the geographic diversification of the exports that represented $5 \%$ of the total of sales to foreign countries.

It seems to be adequate to indicate that the United States of North America continue to be the main receptor of the Mexican exports and that the participation of the imports coming from the US market with respect to the total purchases of Mexico has gone down (went down from $74 \%$ in 1995 to $49 \%$ in 2013).

Summarizing we can say that since the FTA EU-MX came into vigor we cannot see significant changes in the size of commercial flows towards the European Union but we can realize that the European Union is becoming an important provider of Mexico.

\section{THE NEED TO RENEGOTIATE THE FTA EU-MX}

The representatives of the European Union and of Mexico have met to analyse possible modifications that would permit modernizing the agreement in several matters. The European Union has the intention to modernize the FTA because it wants to achieve that the European companies can take benefit from the constitutional reforms that have been introduced to Mexico in the service, telecommunication and energy sector. Meanwhile Mexico would like to obtain a complete liberalisation of the agricultural and fishing products. It would also like to enlarge the part of investments that concerns telecommunications and professional, aerial and maritime services.

After these exploratory meetings the European Commission will elaborate a report and analyse the situation at the moment and after a possible reform with the final objective to take a final decision. So, the European Union will try to realize certain changes in the chapter of financial services and will include a chapter related to sustainable development that establishes clear and binding commitments. Meanwhile the authorities of Mexico pretend to initiate in 2015 the formal negotiation to update the FTA EU-MX that was signed in 2000 because it is considered that Mexico has taken little benefit from this commercial agreement since the FDI of the EU in Mexico was substantial, but was limited to the buying of companies and has not built new companies that created new jobs and that even resulted in reduction of personal due to the new acquisitions of the companies with capital coming from the EU. And it was said that the FTA EU-MX has not permitted that the small and medium-sized Mexican companies have developed. 
By carrying out this revision the FTA EU-MX is also looking for the adaption of the transatlantic negotiation that is taking place between the European Union and the three states parts of the NAFTA. At this time the European Union and Canada have signed the Comprehensive Economic and Trade Agreement (CETA) that tries to make access of European services (finance, telecommunication and transport) easier to the Canadian market. Meanwhile the European Union and the United States of North America are negotiating the Transatlantic Trade and Investment Partnership (TTIP).

With all these negotiations the three state members of NAFTA (Mexico, United States of North America and Canada) want to strengthen their commercial relations with the European Union with the signing of bilateral agreements, but considering their markets and the commitments assumed by them in the NAFTA. This way, we think, that the revision of the FTA EU-MX is an excellent opportunity to modernize it, adapt it in a better way to the requirements of the parties interested in it and to find new areas of convergence between Mexico and the European Union.

\section{CONCLUSIONS}

The main objective of the FTA-EU-MX was to increase trade between the EU and Mexico and to incentivize investments in Mexico. After analysing the facts we come to the conclusion that imports from the EU to Mexico have increased. The exports from Mexico to the EU have increased as well; however, the increase has not been as high as expected because the Mexican companies need to improve certain aspects related to the competitiveness and innovation in technology. Considering this it would be favourable to promote that entrepreneurs from Mexico have more possibilities to compete with producers of the European Union. The Mexican government could provide financial support and invest more in infrastructure or technology and they need to explore new markets that would be relevant for the interaction with the European market.

Another reason for Mexico to establish the FTA-EU-MX was to reduce the dependence of the United States of North America. With the signing of the FTA EU-MX it was tried to diversify the origin and destination of commercial interchange of goods and services. Mexican exports, however, still largely depend on the United States of North Ameri$\mathrm{ca}$ as the major destination. In fact a great number of European companies use Mexico as a platform to enter into the North American market and they do not manifest a real interest or intention to invest into the Mexican market and its industry on a long term basis.

With regard to the impact of the FTA EU-MX on the SMEs of Mexico we come to the following conclusion. It is necessary that the small and medium-sized Mexican companies participate more in the productive chains and that they are taken into account by the European companies established in Mexico for possible cooperation. By strengthening the importance, influence and impact of the Mexican companies, more benefits will be generated for a greater number of Mexican people, regions and cities. The Mexican state could support this by providing instruments of development and necessary resources as well as financial incentives. 
Considering that Mexico is an important interlocutor in the economy and trade relations on a global level and an important part in the interrelation between the NAFTA and the FTA EU-MX it is necessary to consider a new dialogue between Mexico and the EU that will permit the adaption of the FTA EU-MX to the scenario at the moment and to enhance better benefits for Mexico and its economy. In this dialogue it is fundamental to give attention to the interests and concerns of the civil society as a whole with the objective to give the FTA EU-MX a real scope that allows to create and to develop new poles of development of benefits for Mexico and the state members of the European Union.

\section{CITED BIBLIOGRAPHY}

AlCÁntara, Héctor (2013): “Una visión prospectiva de las relaciones económicas entre México y Alemania”, Revista Mexicana de Política Exterior, Vol. 99: pp. 33-59.

Chacón, Mario (1996): "Relaciones económicas entre México y la Unión Europea: evolución reciente", Revista Mexicana de Politica Exterior, Vol. 49: pp. 159-193.

Conde, Raúl (2004): "Las micro, pequeñas y medianas empresas: su comportamiento reciente en el crecimiento y desarrollo económicos de México", in VIDAL, Gregorio (coord.), México en la región de América del Norte. Problemas y perspectivas (México D.F.: Cámara de Diputados de México, Universidad Autónoma Metropolitana, INTAM y Miguel Ángel Porrúa - Grupo Editorial), pp. 78-103.

CRUZ, Rodolfo (2003): Las relaciones comerciales multilaterales de México y el Tratado de Libre Comercio con la Unión Europea (México D.F.: Ed. Universidad Iberoamericana y Universidad Nacional Autónoma de México), pp. 153-237.

Delegación De la Comisión Europea En México (2001): "El comercio potencial entre la Unión Europea y México”, Europa en México, Año 2, N³: pp. 17-18.

European Commission (2014): “Mexico: Country Strategy Paper 2007-2013”. Document E/2007/1063, pp. 1-28. May be consulted in: https://ec.europa.eu/ europeaid/sites/ devco/files/csp-mexico-2007-2013_en.pdf. Date of consultation: February 17 ${ }^{\text {th }}, 2015$.

Gómez, Irma (2005): "El Acuerdo Global, un logro para la política exterior de México", in Piñón Antillón, Rosa María (coord.), El Acuerdo Global entre México y la Unión Europea: Balance y Perspectivas (México D.F.: Fundación Friedrich Ebert, DGAPA, UNAM), pp. 67-75.

GonzÁlez, Sergio (2003): "Aspectos políticos del Acuerdo de Asociación económica, concertación política y cooperación México - Unión Europea: Posibilidades y eventuales problemas", in Morales Pérez, Eduardo (coord.), Las relaciones de México con la Unión Europea (México D.F.: El Colegio Mexiquense), pp. 139-178.

Green, Rosario (2000): "La agenda política y de cooperación en la nueva relación entre México y Europa”, El Mercado de Valores, Junio: pp. 4-5.

Guillén, Arturo (2013): "La crisis europea: una prolongación de la crisis global”, Mundo Siglo XXI, Revista del CIECAS-IPN, No 29, Vol. VIII: pp. 23-41.

Gutiérrez-Haces, María Teresa (2014): “Incidencia del TLCAN y de los acuerdos de protección a la inversión extranjera sobre las relaciones de México con la Unión Europea”, Economía UNAM, Vol. 11, N³1: pp. 25-52. 
Krugman, Paul and Obstfeld, Maurice (2001): Economía Internacional: Teoría y Práctica (Madrid: Pearson Educación, S.A., quinta edición).

Manrique de Luna, Antonio (2015): "The Free Trade Agreements between the EU and Latin America. The Peruvian and Mexican case", Challenges of the Knowledge Society. Political Sciences, European Studies and International Relations, pp. 817-827.

Organización Mundial del Comercio (2013): Informe sobre el Comercio Mundial. Factores que determinan el futuro del comercio (Ginebra: Publicaciones de la Organización Mundial del Comercio), pp. 38-52.

Piñon Antillón, Rosa María (2005): "El Acuerdo Global: ¿una nueva era en las relaciones entre México y la Unión Europea?”, in Piñón Antillón, Rosa María, El Acuerdo Global entre México y la Unión Europea: Balance y Perspectivas (México D.F.: Fundación Friedrich Ebert, DGAPA, UNAM), pp. 17-65.

RuANo, Lorena (2013): "Inercia institucional en un ambiente difícil: las relaciones de México con Europa durante la administración de Felipe Calderón, 2006-2012”, Foro Internacional 213-214, LIII (3-4): pp. 619-644.

Sanahua, José Antonio (2013): Hacia un nuevo marco de relaciones entre la Unión Europea y América Latina y el Caribe (Hamburgo: Fundación EU-LAC), pp. 1-32.

Sánchez, Genaro (2014): Perspectivas de las micro y pequeñas empresas como factores del desarrollo económico de México. May be consulted in: http://herzog.economia.unam.mx/ profesor/ barajas/perspec.pdf. Date of consultation: December 3, 2014.

Thorpe, Adrián (2003): "México y el TLC con Europa: el punto de vista bilateral", in DE Olloqui, José Juan (coord.), Jornadas sobre México y los tratados de libre comercio (México: Instituto de Investigaciones Jurídicas de la UNAM), pp. 89-94.

\section{LEGAL NORMS}

Acuerdo de Asociación Económica, Concertación Política y Cooperación (Acuerdo Global) de 8 de diciembre de 1997.

Constitución Política de los Estados Unidos Mexicanos de 5 de febrero de 1917.

Ley de Inversión Extranjera de 27 de diciembre de 1993.

Ley para el desarrollo de la competitividad de las micros, pequeñas y medianas empresas de 30 de diciembre de 2002. 
